funksjonærer jobber blant. Alle disse avsnittene overbeviser om at begrepene er viktige når det gjelder å forstå mange brukere og deres livssituasjon. Her er også gode eksempler på å forklare hvorfor tiltak ikke fører frem. Et eksempel er mislykket attføring av mennesker som må flytte for å ha sjanse til en jobb, men som ikke kan risikere å gi opp det sosiale nettverket de strever for å ha på hjemstedet.

Derimot er det vanskelig å finne gode eksempler på at teorien om sosial kapital kan brukes til å formulere gode tiltak i velferdsarbeid. I vårt land er mye allerede gjort, f.eks. å organisere eldresentre, boenheter for psykisk utviklingshemmede og mye annet. Nye forslag er ikke lett å komme med. Men de bør komme, f.eks. i skolene og i barnevernet. Således er denne boken svært velkommen.

\section{Bjørgulf Claussen}

Institutt for helse og samfunn

Universitetet i Oslo

\section{Dansk seniorpolitikk - apokalypse nå!}

Ishøy T, red.

\section{Alle disse løfter om et tidssvarende} sundhedsvæsen

En debatbog om de danske sygehuse. 285 s, tab, ill. København: Forlaget Vandkunsten, 2010. Pris DKK 229

ISBN 978-87-7695-156-6

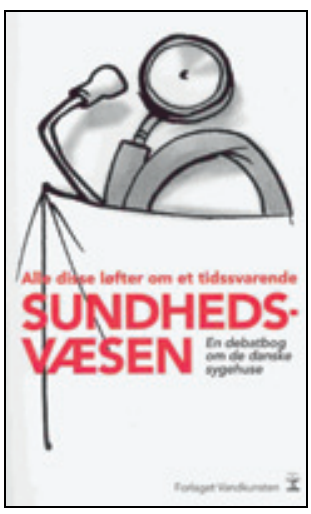

Da jeg leste denne boken, var det raskt to danske organisasjoner jeg måtte google. Den ene var Dansk Selskab til Sikring af Lægers Ytringsfrihed (DSLY; $h t t p: / / d s l y . d k /)$. I deres formålsparagraf står det bl.a: «Selskabets formå er at sikre lægers ytringsfrihed i overensstemmelse med gældende love, vedtægter og internationale deklarationer til gavn for patienterne og sundhedsvæsenet. Samtidig vil selskabet støtte medlemmer, der kommer i knibe i forhold til ytringsfriheden og søge at forhindre, at dette sker i fremtiden (...).»

Den andre organisasjonen, som i boken fremstår som den store stygge ulven, heter DJØF. Det er tydelig at bokens redaktør, Torben Ishøy, tar det som en selvfølge at alle lesere vet hva disse bokstavene står for, men det visste altså ikke jeg. DJØF er forkortelsen for Danmarks jurist- og økonomforbund, og på hjemmesiden (www.djoef.dk/) heter det: «DJØFs over 69.000 medlemmer arbejder bl.a. med jura, økonomi, administration, forvaltning, forskning, undervisning, kommunikation og ledelse.»

Når jeg nevner dette, er det fordi jeg lurer på om en bok som denne i det hele tatt ville kunne bli utgitt i Norge. Her har vi ingen egen organisasjon (utenfor Legeforeningen) til å ivareta legenes ytringsfrihet, men opplever heller ikke en så massiv og konkret legefiende som DJØF tydeligvis er.

Hva handler så denne boken om? Den presenteres som en debattbok om de danske sykehusene. Det kan man trygt si at den er, bortsett fra at det ikke foregår noen debatt i selve boken. Den representerer en samstemt og kraftig bredside mot danske samfunnsinstitusjoner, og i særdeleshet helsevesenet og måten sykehusene drives på. 15 av de 16 bidragsyterne er mannlige nåværende og pensjonerte overleger og professorer, den siste er kvinnelig sykepleier med samme etternavn som en av overlegene. Gjennomsnittsalderen for de debatterende legene er 69 år, med et spenn fra 53 år til 91 år.

Dette bør selvsagt ikke nødvendigvis svekke sakligheten. Pensjonerte leger kan komme med offentlig kritikk av systemet uten å risikere å miste jobben, en risiko som også finnes her til lands (1). Dessuten er det ikke utenkelig at en eldre erfaren overlege kan komme med nyttige og konstruktive forslag til endringer og forbedringer av systemene.

Dessverre er det ikke konstruktive forslag som preger denne boken. Den fremstår, med noen få hederlige unntak, som en endeløs klagesang, stort sett over temaet «alt var mye bedre før». Flere av innleggene bekrefter alle forestillinger om eldre mannlige overleger som arrogante besserwissere, og både sykepleiere og pasienter får sine pass skikkelig påskrevet. Men hovedfienden er de før omtalte DJØF-erne. Vi kjenner denne type beskrivelser fra norske humorister, for eksempel i en artikkel om kunsten å svømme blant haier (2), bare at her er det blitt blodig alvor. Som redaktøren Torben Ishøy skriver i sin lange og nokså snirklete klagesang: «Bureaukrater og hofsnoge har inndtaget væsentlige kontrollposter, som den syge intetanende må passere for at kunde gennemføre den lange vandring opad gennem systemet.»

Et innlegg som skiller seg positivt ut er Lars Heslets «Fremtidens hospital». Han har bl.a. skrevet boken Sansernes hospital (3), og jeg antar hans kapittel er en kortversjon av denne. Han viser på en overbevisende måte hvordan sykehusbyggene, særlig der hvor man må forholde seg til gamle bygninger beregnet på gårsdagens behandlingsregimer, ikke har maktet å følge med i den kunnskapsbaserte teknologiutviklingen, for eksempel ved å fjerne unødvendige stresselementer for personalet og pasienter. Det handler bl.a. om så enkle ting som å redusere støy og sørge for optimale lysforhold.

Det internasjonale perspektivet er totalt fraværende. Den danske nedturen som beskrives blir ikke satt i relieff til andre lands «nedturer». For meg blir dette en samling apokalyptiske skrifter fra en avgående legegenerasjon som er frustrert fordi de ikke selv lenger sitter ved roret. Hvorfor gjorde de ikke mer da de var yngre og saftigere?

\section{Olaf Gjerløw Aasland}

Legeforeningens forskningsinstitutt

\section{Litteratur \\ Aasland OG, Førde R. Legers faglige ytringsfrihet. Tidsskr Nor Legeforen 2008; 128: 1838-40. \\ 2. Iversen $\mathrm{OH}$. Kunsten å svømme blant hai. Tidsskr Nor Lægeforen 2003: 123: 1157-8. \\ . Heslet L. Sansernes hospital. København: Arkitek- tens forlag, 2007}

\section{Nyttig om inflammasjon i mage-tarm-kanalen}

Mayerle J, Tilg H, red.

Clinical update on inflammatory disorders

of the gastrointestinal tract

216 s, tab, ill. Basel: Karger, 2009. Pris CHF 182

ISBN: 978-3-8055-9294-9

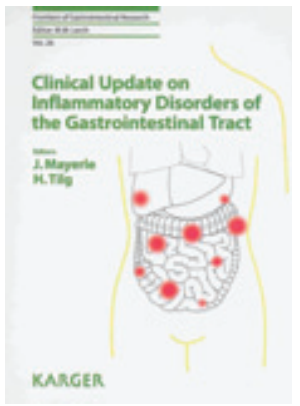

Dette er bind nr. 26 i serien Frontiers of gastrointestinal research og omhandler ulike aspekter ved inflammasjon i mage-tarmkanalen. Det er en ambisiøs oppgave å dekke et så vidtspennende tema

i en bok på ca. 200 sider, men som tittelen antyder, er intensjonen å gi en oppdatering innen feltet, ikke å være en lærebok.

I fire deler (hepatologi, gastroenterologi, pancreassykdommer og ventrikkelsykdommer) presenteres kapitler som i realiteten er isolerte oversiktsartikler av ulike forfattere. De fleste kapitlene omhandler spesifikke temaer, et fåtall omtaler inflammasjon generelt. Fokus varierer fra basalfag til praktiske kliniske problemstillinger, men også nye og mulig fremtidige behandlingsmetoder omtales. Temaene spenner eksempelvis fra immunterapi ved pancreascancer via probiotika ved ulike sykdommer i mage-tarm-kanalen til eradikasjon av Helicobacter pylori. Det virker noe tilfeldig hvilke temaer som er omtalt, og fremstillingen er fragmentert og ufullstendig. På den annen side er majoriteten av kapitlene godt skrevet, gir oversiktlig presentasjon av de enkelte temaene og har gode illustrasjoner. 
Spesielt vil jeg trekke frem kapitlet om anti-TNF-behandling ved inflammatorisk tarmsykdom. Dette er balansert og understreker at det fortsatt er mye uavklart ved denne behandlingen. Bakerst finnes både forfatter- og stikkordindeks.

Dybden og detaljnivået gjør at målgruppen etter mitt syn først og fremst er utøvere av generell klinisk gastroenterologi. En samling av gode oversiktartikler er ofte givende for klinikere. Dermed konkluderer jeg med at boken helt klart er leseverdig uten å være et «must».

\section{Tom Christian Martinsen}

Avdeling for fordøyelses- og leversykdommer St. Olavs hospital

\section{Informativt om kliniske utprøvninger}

Lemne C, Lafolie P.

\section{Handbok för kliniska prövare}

199 s, tab, ill. Lund: Studentlitteratur, 2009 Pris SEK 235

ISBN 978-91-44-05614-2

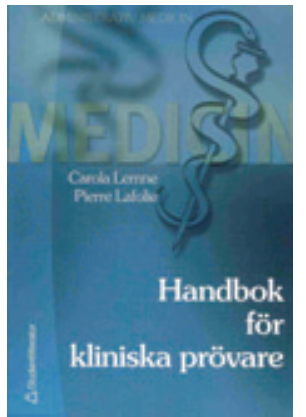

Kliniske utprøvninger er prospektive studier av legemidler, behandlingsmetoder eller medisinsktekniske produkter. Mange leger og annet helsepersonell vil oppleve å bli involvert i slike studier. Uansett hvilken rolle

ulike deltakere har i en klinisk utprøvning er det ønskelig og en fordel at de har en samlet forståelse for de mange fasetter ved utprøvningen. Dette gjelder generell bakgrunnskunnskap, lover og regler som skal følges, og den ganske kompliserte praktiske gjennomføringen, dvs. alt som skal skje i prosessen fra idé til publikasjon. Denne boken gjør det mulig raskt og effektivt å skaffe seg den nødvendige oversikt.

Språket er svensk, formatet er paperback, og forfatterne er to leger med solid erfaring fra kliniske legemiddelutprøvninger. Innledningsvis er det en allmenn del, der det gis definisjoner, og utprøvningenes plass i helsesektoren omtales. Utprøvers og sponsors forpliktelser og ansvar vies også mye plass. Deretter følger omtale av alle aspekter ved praktisk gjennomføring. Særlig nyttig er det at problemstillinger som deltakere på ulike nivåer kan støte på, identifiseres og drøftes. Hovedvekten ligger naturlig nok på omtale av legemiddelutprøvninger som er den type kliniske utprøvninger som har størst omfang i helsesektoren.
Så langt utgjør boken 90 sider. I tillegg er det et appendiks med om lag like mange sider der forfatterne angir nyttige referanser og relevant litteratur, eksempelvis er en engelskspråklig oppdatert versjon av Helsingfors-deklarasjonen skrevet ut. Videre er trykt aktuelle skjemaer, som søknadsskjemaer som skal anvendes ved søknader til svenske etiske komiteer og til Läkemedelsverket. Dette er med på å styrke den praktiske tilnærmingen til temaet. I prinsippet har vi de samme typer søknadsskjemaer i Norge, men i og med at det er svenske forhold og svensk praksis som beskrives, er denne delen mer utbytterik for svenske lesere enn for norske.

Dette er en bok som det er lett å slå opp i, med lett tilgjengelig innhold. Forfatterne evner kortfattet å diskutere hele bredden av relevante problemstillinger. Boken egner seg godt for sammenhengende lesing for dem som vil skaffe seg oversikt over kliniske utprøvninger, men er også velegnet som oppslagsbok for dem som søker svar på spesifikke spørsmål.

Handbok för kliniske prövare fremstår som nettopp det den pretenderer å være, en kortfattet, hendig og praktisk bok om kliniske utprøvninger. Slik en god håndbok skal være.

\section{Åsmund Reikvam}

Farmakologisk institutt

Universitetet i Oslo

\section{Interview for at finde den bedste}

Smith C, Meeking D.

How to succeed at the medical interview

129 s, ill. Chichester: Wiley-Blackwell, 2008.

Pris GBP 18

ISBN 978-1-4051-6729-1

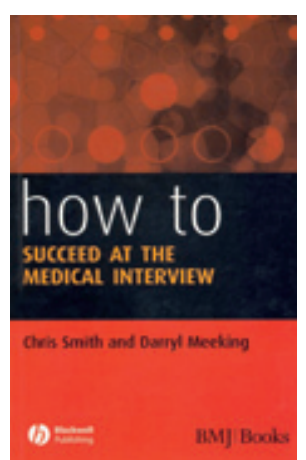

Bogen henvender sig til læger der er ansøgere til stillinger i det britiske helsevæsen, hvor man kan blive indkaldt til interview som supplement til en skriftlig ansøgning. Formålet er at give læseren redskaber til at klare et personligt interview godt og forøge mulighederne for at få en ansøgt stilling. I det britiske helsevæsen har man tradition for at bruge interview til at udvælge ansøgere til studiepladser, uddannelsesstillinger og lægelige slutstillinger. Interview som udvælgelsesmetode for at finde de mest velegnede til medicinske studiepladser har aldrig fået fodfæste i Norden, bortset fra i Odense. Interview bruges i Norden tilfældigt, sporadisk og ofte uprofessionelt ved selektion af ansøgere til uddannelsesstillinger og ledende stillinger på universiteter og sygehuse.

Forfatterne gennemgår interviewet, hvordan man forbereder sig og gennemfører det. Derefter gennemgåes almindelige interview spørgsmål, hvordan man tester viden og «generic skills». Med «generic skills» menes færdigheder, der er vigtige at mestre uanset hvilken lægelig stilling man søger. Det drejer sig om kommunikation, teamarbejde, organisation og ledelse. Til slut gennemgåes en række andre metoder for selektion, som man bruger, når man skal udvælge personer til bestemte uddannelser eller stillinger.

Bogen er letlæst, den er kortfattet, overskuelig, og giver en god indføring i hvordan et interview er opbygget. Den giver konkrete anvisninger på hvad man hensigtsmæssigt kan gøre, så den får karakter af en instruktionsbog. Svagheden er, at den omhandler udvælgelse af ansøgere i det britiske helsevæsen, som i holdning, organisation og tradition ligger milevidt fra Scandinavien. Som eksempel anfører forfatterne: "Generally, the wearing of old school ties is not recommended»! En lang række kommentarer er på dette plan - meget engelsk. Kapitlerne som beskæftiger sig med den viden, man skal have, for at klare sig godt $i$ et interview, giver sparsom generel information, men megen speciel information om forhold i det britiske helsevæsen. Bogen giver for lidt generel information til, at den kan anbefales som håndbog i Scandinavien. Der bør skrives en nordisk bog, dels for at professionalisere det medicinske ansættelsesinterview til gavn for så vel interviewere og interviewede, og dels for at kunne bruge interviewet professionelt, der hvor det er velegnet! En sådan bog vil kunne belyse interviewets fordele og begrænsninger, og afmystificere brugen af det. Interview bør også i Norden være et professionelt hjælperedskab i udvælgelse af studerende til medicinstudiet, af yngre læger til uddannelsesstillinger og læger der søger slutstillinger i almen praksis, på sygehuse og universiteter.

\section{Niels Bentzen}

Medisinsk-teknisk forskningssenter Institutt for samfunnsmedisin

Norges teknisk-naturvitenskapelige universitet 